\section{Influence of Industry 4.0 technologies on corporate operation and performance management from human aspects}

\author{
Nóra Obermayer and Tibor Csizmadia
}

Department of Management, University of Pannonia, Veszprem, Hungary, and

Dávid Máté Hargitai

Department of Marketing, University of Pannonia, Veszprem, Hungary
Influence of

Industry 4.0

technologies

Received 28February 2021

Revised 13 July 2021

23 September 2021

28 October 2021

Accepted 6 November 2021

\begin{abstract}
Purpose - The purpose of this paper is to discover how Hungarian manufacturing companies interpret technology and human resources as driving forces and barriers in terms of Industry 4.0 implementation.
\end{abstract}

Design/methodology/approach - The authors conducted 23 semi-structured interviews with corporate leaders and applied qualitative content analysis using Atlas.ti software.

Findings - The authors formulated a new definition of Industry 4.0 which emphasises the role of human factors. The authors identified driving forces (efficiency with speed/information flow/precision) and barriers (technology compatibility, human fears and lack of digital skills) in terms of Industry 4.0 implementation and developed the DIGI-TEcH performance management dimensions.

Research limitations/implications - Comparison with other countries is limited. Given the exploratory and qualitative nature, further quantitative research would be needed to generalise results. Finally, only manufacturing companies are examined.

Practical implications - It provides empirical evidence to practitioners to understand concerns about technology and human resource in terms of Industry 4.0 implementation. In addition, corporate performance management can be extended by the developed DIGI-TEcH dimensions.

Originality/value - This paper reveals key evidence for the uptake of technology and human factors in terms of Industry 4.0 implementation and their impacts on corporate operation and performance. It also provides an insight into a specific country context, which can be a useful benchmark for other Central and Eastern European countries.

Keywords Performance management, Technology, Human resource, Manufacturing, Barriers, Industry 4.0, Driving forces

Paper type Research paper

(C) Nóra Obermayer, Tibor Csizmadia and Dávid Máté Hargitai. Published by Emerald Publishing Limited. This article is published under the Creative Commons Attribution (CC BY 4.0) licence. Anyone may reproduce, distribute, translate and create derivative works of this article (for both commercial and non-commercial purposes), subject to full attribution to the original publication and authors. The full terms of this licence may be seen at http://creativecommons.org/licences/by/4.0/legalcode

This work was supported by the TKP2020-NKA-10 project financed under the 2020-4.1.1TKP2020 Thematic Excellence Programme by the National Research, Development and Innovation Fund of Hungary.

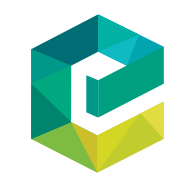

Meditari Accountancy Research Vol. 30 No. 4, 2022 ol. 30 No. 4,2022 Emerald Publishing Limited 2049-372X DOI 10.1108/MEDAR-02-2021-1214 
MEDAR

30,4

1028

\section{Introduction}

One of the biggest challenges that organisations face today is finding the proper way to shape competitive advantages including the impact of digital transformation on corporate operation and performance in the age of Industry 4.0. It is a condition of their long-term survival in the market. Industry 4.0, a German strategic initiative, is aimed at generating a transformation from machine-dominant manufacturing to digital and intelligent manufacturing (Zhong et al., 2017). To achieve a successful digital transformation, Industry 4.0 promises to increase flexibility and interconnectivity in manufacturing (Castelo-Branco et al., 2019), along with growing mass customisation and improved productivity (Trstenjak and Cosic, 2017; Zhong et al., 2017). It enables companies to be highly efficient and to cope with the challenge of producing individualised products with a short lead-time to market and higher quality (Wittenberg, 2016; Zhong et al., 2017). The potential of Industry 4.0 lies in better flexibility and scalability of manufacturing systems through information technologies and industrial automation (Brettel et al., 2014; Dassisti et al., 2019).

Nowadays digital manufacturing plays an essential role in the world, especially in European countries (Qin et al., 2016). Blanchet et al. (2014) and Blanchet and Rinn (2016) state that industrial production has a prominent role in the EU economy, and industry is the main driver of research, innovation, job creation and export. Manufacturing industry accounts for $80 \%$ of the EU's innovation output and $75 \%$ of its exports, while its role in the economy of Central and East Europe is much higher than the EU average (Nagy et al., 2020). Hungary is one of the most industrialised countries in Europe with industry's share of gross domestic product (GDP) at 24.1\% in 2019 (KSH, 2019), with economic performance highly dependent on car manufacturing and its related industries (Pongrácz and Nick, 2017). At the government level, and in line with the European Union's reindustrialisation strategy, the Ministry for National Economy (2016) intends to foster digitisation and industrial automation by developing its own reindustrialisation strategy, which the government identified as the Strategic Programme for Innovative Industrial Development. However, Nagy et al. (2018) note that while Hungary is among the most industrialised countries in Europe in terms of manufacturing output versus GDP, the country is below the European average in terms of Industry 4.0 indicators such as digital production processes, degree of automation and workforce readiness. Horváth and Szabó (2019) state that digital technology and human resources are identified as both the main driving forces and barriers to implementing Industry 4.0.

Hence, the paper aims to answer the following research question:

$R Q$. What are the driving forces and barriers of Industry 4.0 in terms of technology and human resource factors?

The objective of this paper is therefore to discover how manufacturing companies operating in Hungary interpret these two important factors, technology and human resource, in terms of Industry 4.0. This paper makes two potential major contributions to the body of knowledge. First, it reveals some key evidence for the uptake of technology and human factors as driving forces and barriers in terms of Industry 4.0 implementation and their impacts on corporate operation. The findings of this study expand our understanding of how corporate efficiency can be increased taking into account human and technology aspects as well. They also lead to new insights into how workforces' resistance and fears can be decreased. Second, it provides an insight into a specific country context, which can be a useful benchmark for other Central and Eastern European countries.

The rest of this paper is organised as follows. Section 2 provides the theoretical background of the study. In Section 3, the method of empirical data collection is outlined and 
content analysis is introduced. This is followed by the empirical findings and discussion in Section 4. Section 5 provides conclusions and presents some limitations to our research.

\section{Literature review}

The literature review briefly outlines the concept of Industry 4.0 and discusses the challenges of implementing Industry 4.0.

\subsection{Concept of Industry 4.0}

In recent centuries, innovation in the form of industrial revolutions made everyday life easier, and the efficiency of production systems has increased, thanks to new technological solutions (Xu et al., 2018). The first three industrial revolutions realised high productivity increases, driven by fast-spreading general-purpose technologies: mechanisation, electricity and information technology (IT) (Kagermann et al., 2013; Veza et al., 2015). The first industrial revolution, at the end of the 18th century, was about the replacement of human and animal muscle power with the invention of the steam engine (Berg and Hudson, 1992). This was followed by the second revolution at the turn of the 20th century, when electricity and mass production - associated with the name "Ford" - became widespread (Mokyr, 1998). In the third case, in the second half of the 20th century, due to the development of electronics and IT, production automation began (Greenwood and Jovanovic, 1999; Ghobakhloo, 2018; Kagermann et al., 2013). Today, the fourth industrial revolution can be considered as the new digital revolution, which fundamentally changes industry and business, as well as the economy and civil society (Demeter et al., 2019; Horváth and Szabó, 2019; Nagy, 2019).

Industry 4.0 differs from previous revolutions in that it relates to all fields of life (Ś lusarczyk, 2018). In the definition of Lasi et al. (2014, p. 240):

\footnotetext{
"Industry 4.0 describes the increasing digitization and automation of the manufacturing environment, as well as the creation of digital value chains to enable communication between products, their environment and business partners."
}

Industry 4.0 describes the increasing digitisation of the whole supply chain, which makes it possible to connect objects and systems based on real-time data exchange (Dorst, 2015); thus, products, machines and processes with artificial intelligence will be able to adapt to changing environmental factors (Hecklau et al., 2016; Magistretti et al., 2019).

Industry 4.0 affects the business world in three main areas (Veeraraghavan and Punjabi, 2018): digitisation and integration of vertical and horizontal value chains: cloud computing, mobile devices and Internet of Things (IoT) platforms; digitisation of product and service offerings: augmented reality, multi-level customer interactions and customer profiling, big data analytics and advanced algorithms and smart sensors; and digital business models and customer access: three-dimensional printing, authentication and fraud detection, advanced human-machine interfaces and location detection technologies (Figure 1).

Digital transformation connotes challenges that seem to differ from the previous technological shifts. Numerous organisations are in a critical situation caused by the variety of traditional businesses, due to the way digital transformation is making obsolete how organisations manage their business processes and create value (D'Ippolito et al., 2019; Appio et al., 2021). They need to adopt digital transformation strategies, leveraging digital technologies to transform value creation (Correani et al., 2020). To reinvent business models is becoming mandatory in the attempt to survive in the changing digital world (D'Ippolito et al., 2019). The adaptation of certain technologies is necessary to accomplish this digital transformation (Ardito et al., 2019a). 
MEDAR

30,4

1030

Figure 1.

Industry 4.0

framework and

contributing digital

technologies

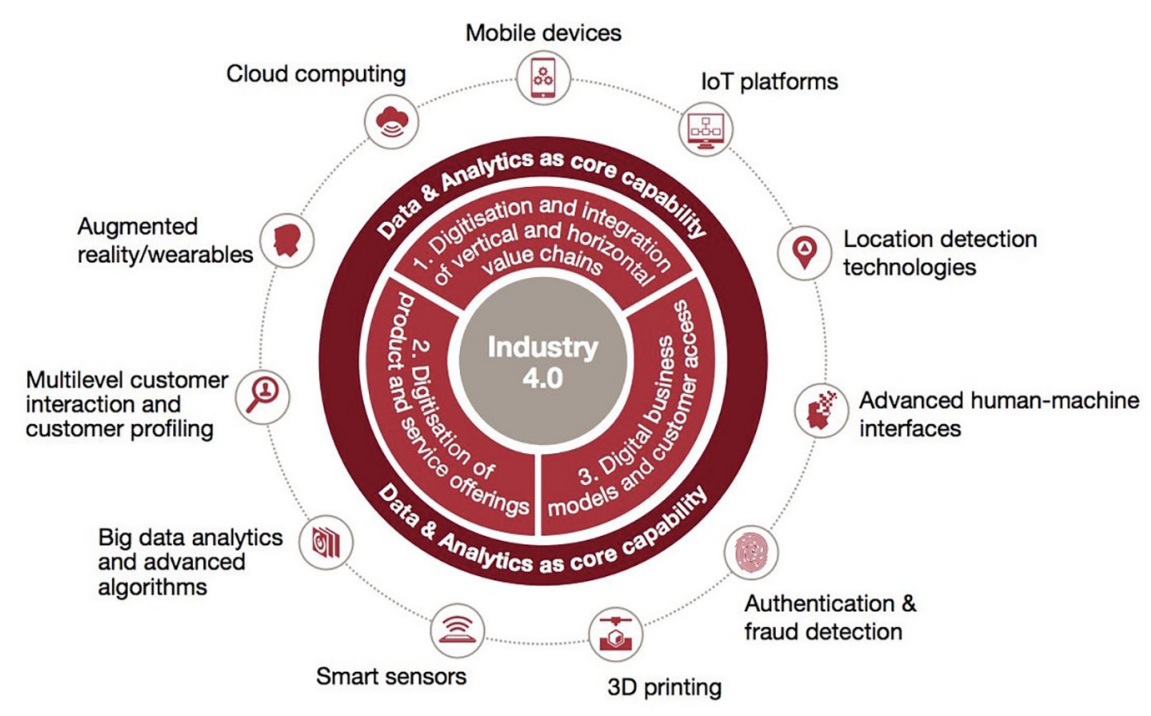

Source: Veeraraghavan and Punjabi (2018)

The study of Ceipek et al. (2020) points to the importance of considering both motivation and ability when examining organisations' behaviour, particularly in the case of digital technologies characterised by specific motivation and ability barriers.

2.1.1 Industry 4.0 in Europe and Hungary. Industry is one of the most important pillars of the European economy. The manufacturing sector in the European Union accounts for 2 million enterprises, 33 million jobs and 60\% of productivity growth (European Commission, 2017). As Industry 4.0 aims to reshape all manufacturing processes and operations, a number of European initiatives appeared (like "Factories of the Future") where significant investments have been made and more than 2,000 organisations have been involved through 240 projects (Pazin, 2017). The European Commission (2017) launched the European platform of 13 national initiatives, including Hungary (Ipar 4.0) on the digitising industry.

In Europe, Industry 4.0 is defined by "group of rapid transformations in the design, manufacture, operation and service of manufacturing systems and products" (Davies, 2015, p. 2).

We are living in a knowledge society, in which autonomous machines are inevitable (Horváth and Szabó, 2019; Kaivo-oja et al., 2017). In Europe, each country faces social challenges including reduced workforce numbers because of a declining population and ageing society (Kaasinen et al., 2020; Jankowska and Götz, 2017; Wang et al., 2016). This can be one of the reasons for applying new technologies (Wang et al., 2016), and moreover, Nagy (2019) noted that previous production systems were outdated and do not fulfil today's expectations.

Automotive and electronics companies operating in Hungary have already started some Industry 4.0 developments, primarily because of the pressure from the international parent company or the Hungarian leadership's motivation to become innovative and agile. The most important success factors in manufacturing are IT developments and flexibility, which have an impact on financial results (Nagy et al., 2018). 


\subsection{Overview the challenges of implementing Industry 4.0}

In addition to understanding the concept of Industry 4.0, it is important to discover the peculiarities that may motivate companies to adopt this new approach.

The drive to digitise business processes is fostered by achieving higher corporate performance and competitive advantages. Performance management provides information that quantifies the efficiency and effectiveness of corporate actions (Neely, 2005) to support strategy and decision-making (Constantiou and Kallinikos, 2015). It facilitates performance goals, controls activities (George et al., 2016) and workforces through different indicators. Digitalisation turned the traditional processes into digital ones where information is digitally represented. In such a changing and competitive environment, management must reconsider the strategy and modify the performance management (Sahlin and Angelis, 2019). With technological developments, new opportunities within performance management emerge; hence, there have been calls for more research in this area. Measuring and managing performance have been studied by some researchers (Neely, 2005; Jääskeläinen and Sillanpää, 2013); however, there has been limited research specifically focussing on the driving forces and barriers. Moreover, there are papers (Melnyk et al., 2014; Peters et al., 2016) investigating performance management based on digital technologies, but there are no literature reviews describing fundamental indicators of performance management in a highly digitalised environment (Sahlin and Angelis, 2019).

2.2.1 Technology. Industry 4.0, as a new paradigm of smart and autonomous manufacturing (Bai et al., 2020), refers to the intelligent networking of machines and processes for industry with the help of information, communication and intelligence technologies (Wang et al., 2017; Jeschke et al., 2017). In other words, the technological aspects of Industry 4.0 can be addressed by the application of the generic concepts of cyber-physical systems and industrial IoT to the industrial production systems (Rojko, 2017; Ardito et al., 2018; Ceipek et al., 2020). Interconnectedness and the compatibility of system elements are fundamental components of this approach (Aichholzer et al., 2015). Bai et al. (2020) grouped Industry 4.0 technologies into digital and physical technologies. Digital technologies mainly refer to modern information and communication technologies, such as cloud computing, blockchain (Madolla et al., 2019), big data analytics (Secundo et al., 2017; Del Vecchio et al., 2018; Ardito et al., 2019b) or simulation (Liao et al., 2017). Physical technologies mainly refer to manufacturing technologies such as additive manufacturing, sensors, drones or radio frequency identification (Morrar et al., 2017; Gibson et al., 2014). Some recent studies summarised these various Industry 4.0 technologies (Bai et al., 2020; Dalenogare et al., 2018; Oztemel and Gursev, 2020). In addition, a growing research interest relates to assessing the current level of maturity of Industry 4.0 technology. Schumacher et al. (2016) and Gracel and Lebkowski (2018) summarised these Industry 4.0 maturity models, highlighting the most comprehensive ones as: IMPULS - Industry 4.0 Readiness (Lichtblau et al., 2015), Industry 4.0/Digital Operations Self-Assessment (Geissbauer et al., 2016) and Industry 4.0 Maturity Model (Schumacher et al., 2016). The models include different maturity dimensions and maturity items for the assessment of Industry 4.0 maturity in manufacturing companies.

Researching the driving forces and barriers of these technologies is a hot topic in academic papers. Among the litany of driving forces, Industry 4.0 technologies can provide manufacturing companies with higher efficiency and quality and improved workplace conditions (Hofmann and Rüsch, 2017; Liao et al., 2017); moreover, performance management is developing by adopting digital technologies (Robert et al., 2020). Rojko (2017) stated that smart technologies can significantly reduce production, logistical and quality management costs. Industry 4.0 technologies help to manage production planning and scheduling, capacity utilisation, maintenance and energy management (Szalavetz, 2019),
Influence of Industry 4.0 technologies

1031 
MEDAR

30,4

1032

faster decision-making and more efficient knowledge management (Cimini et al., 2017; Uden and He, 2017) and radical micro-level performance improvements (Robert et al., 2020; Losonci et al., 2019). At the same time, a number of barriers were also identified. Kiel et al. (2017b) have suggested that low degrees of standardisation, poor understanding of integration and concerns about cybersecurity and data ownership are also a significant obstacle to Industry 4.0 implementation. Nagy (2019) determined that standardisation problems may occur in the tools and systems inside manufacturing companies. Kovács (2017a, 2017b) highlighted that the new technologies cause fear about the safe handling of information and data.

This paper contributes to this debate surrounding the driving forces and barriers of Industry 4.0 technologies by revealing empirical evidence of Hungarian manufacturing companies. Thus, from a technological point of view, we formulate the following propositions:

P1a. The driving forces of the implementation of Industry 4.0 focus mainly on measurable characteristics.

P1b. The barriers of the implementation of Industry 4.0 are the lack of standardisation and adoption problems.

2.2.2 Human resource. Manufacturing has evolved from manual processes to advanced automation able to ensure a maximum degree of efficiency. This will result in erasing a huge amount of low-skilled jobs. New technologies of Industry 4.0 will improve the autonomy of workforces, but the demand for high-skilled workers (with advanced digital competences) will rise, as the new approach requires collaboration between humans and machines (Tabarés et al., 2018). This is a great challenge for the European industry. In 2019, the percentage of people who have at least basic digital skills reached 58\%; however, a large part of the EU population still lacks basic digital skills, even though most jobs require such skills (European Commission, 2020). Industry 4.0 is at a stage where people are sceptical about new technologies. Employees are afraid that digital solutions (mainly physical robots) will lose their jobs (Kinzel, 2017). It can happen, but it is important to introduce, on the one hand, possibilities for learning and, on the other hand, that new technologies make work easier (Nagy, 2019). According to several studies, one of the biggest challenges in implementing Industry 4.0 technologies is that organisations do not have skilled workers and a requirement to retrain staff to fit changed circumstances (Shamim et al., 2016; Müller et al., 2018; Kiel et al., 2017a; Horváth and Szabó, 2019).

Nagy et al. (2018) determined in their survey that when organisations had tried to introduce new technologies to their employees, there were cases where the workers accepted or refused. Companies all adopted new technologies to support their workforces (Nelles et al., 2016; Wang et al., 2016), and those unwilling to work with new tools will have to find new jobs. The organisational resistance mostly comes from employees who are afraid of losing their jobs. Moreover, the lack of understanding of the new technology, and the employees' fear of the unknown are evident (Horváth and Szabó, 2019). A survey conducted by the Massachusetts Institute of Technology found that teams made of humans and robots collaborating efficiently can be more productive than teams made of either humans or robots alone. Robots and machines are seen not as a threat to employees but rather as their assistants or teammates, who share a workspace together and complement each other (Koleva, 2019). An automated system can support the workforce and can provide active physical assistance that compensates, for example, decreasing human capability as the age of employees increases (Saggiomo et al., 2016; Wang et al., 2016; Jankowska and Götz, 2017). 
Machines can be a real assistant for humans and can assume an equal role as a collaborator, sharing tasks according to their respective strengths (Wang et al., 2015). Therefore, our propositions from a human perspective are as follows:

P2a. The biggest challenges of implementation of Industry 4.0 stem from the fear of employees and the lack of digital skills.

$P 2 b$. The implementation of Industry 4.0 is not designed to replace human workforces but to support them.

\section{Research methodology}

As the objectives of this study are more related to understanding than measuring companies, the case study was considered the most appropriate methodology. The benefit of a case study approach lies in its aim to undertake an in-depth investigation of a contemporary phenomenon in its real-life context (Yin, 2014). We conducted an exploratory case study to understand the antecedents and limitations in Industry 4.0 implementations in Hungarian manufacturing companies. The research methodology consists of data collection and analyses.

\subsection{Data collection}

Data were gathered qualitatively, carrying out semi-structured interviews mainly with the chief executive officers or with functional managers of companies in Hungary. They were chosen because they possess insight and breadth of perspective related to questions central to this study. A total of 23 interviews were carried out in manufacturing companies between January and February 2020 (Table 1). These companies comprise a broad overview of technology trends in Hungary with respect to factory automation, robotics, threedimensional printing and other Industry 4.0 solutions. An email was sent out to the chosen companies, introducing the research and requesting an interview. Once the interview request was accepted, a date and time were agreed. All interviews lasted between 50 and $70 \mathrm{~min}$ and were all recorded and transcribed verbatim to facilitate detailed and systematic analysis. Issues of confidentiality and anonymity were confirmed. A confirmation letter explaining what the study involved, reaffirming the interviewee's voluntary participation and describing the use of the data were signed by all participants. All personal information was removed, and the companies were renamed with letters and numbers (C1-C23). A precomposed interview framework (Appendix 1) consisted of open questions which were communicated to respondents in advance. This gave the interviewees ample time to prepare for specific topics they considered relevant. The framework questions were grouped into three main fields, i.e. the implementation of Industry 4.0 and its interpretation, the leaders' perspectives on driving forces and barriers for Industry 4.0 implementation and the needs for training. Besides interviews with company leaders, secondary data, such as annual revenue and the number of employees, were gathered from the official open Hungarian Government database (https://e-beszamolo.im.gov.hu) in 2020.

\subsection{Content analysis}

For this study, we only used Questions 1, 5 and 6 for the analysis. As part of the analysis phase, we organised the texts and recordings, using the computer-based software ATLAS.ti (version 7). The software was used to code and categorise the transcribed texts for outstanding themes. The themes were analysed for relevance to our research question. 


\section{MEDAR \\ 30,4}

\begin{tabular}{|c|c|c|c|c|c|}
\hline Pseudonym & Respondent's job title & Main activity & $\begin{array}{c}\text { No. of } \\
\text { employees } \\
2019\end{array}$ & $\begin{array}{c}\text { Net } \\
\text { revenue } \\
\text { (EUR) } 2019\end{array}$ & $\begin{array}{c}\text { Date of } \\
\text { interview }\end{array}$ \\
\hline $\mathrm{C} 1$ & Production Manager & $\begin{array}{l}\text { Manufacture of construction } \\
\text { machinery }\end{array}$ & 153 & $11,913,306$ & 02.02 .2020 \\
\hline $\mathrm{C} 2$ & CEO & Metalworking & 13 & 86,642 & 02.02 .2020 \\
\hline C3 & $\begin{array}{l}\text { Business Unit } \\
\text { Manager }\end{array}$ & Metalworking & 134 & $6,152,887$ & 14.02 .2020 \\
\hline $\mathrm{C} 4$ & HR Manager & $\begin{array}{l}\text { Manufacture of vehicle engine } \\
\text { parts }\end{array}$ & 524 & $12,641,707$ & 09.01.2020 \\
\hline C5 & Logistics Manager & $\begin{array}{l}\text { Manufacture of vehicle engine } \\
\text { parts }\end{array}$ & 697 & $59,116,684$ & 06.02 .2020 \\
\hline $\mathrm{C} 6$ & $\mathrm{CEO}$ & Metalworking & 4 & 132,776 & 13.01.2020 \\
\hline $\mathrm{C} 7$ & CEO & Special machine building & 127 & $11,934,046$ & 09.01 .2020 \\
\hline $\mathrm{C} 8$ & CEO & $\begin{array}{l}\text { Manufacture of ceramic } \\
\text { household }\end{array}$ & 710 & $15,717,218$ & 15.01 .2020 \\
\hline C9 & CEO & Manufacture of other furniture & 35 & 258,947 & 17.01.2020 \\
\hline $\mathrm{C} 10$ & CEO & Manufacture of workw & 54 & 2,523,188 & 06.02 .2020 \\
\hline C11 & Operations Director & $\begin{array}{l}\text { Manufacture of other general- } \\
\text { purpose machinery }\end{array}$ & 827 & $165,320,080$ & 06.01 .2020 \\
\hline $\mathrm{C} 12$ & $\begin{array}{l}\text { Business } \\
\text { Development } \\
\text { Manager }\end{array}$ & Printing industry & 51 & $2,154,012$ & 07.02 .2020 \\
\hline $\mathrm{C} 13$ & $\begin{array}{l}\text { Product Safety } \\
\text { Manager }\end{array}$ & $\begin{array}{l}\text { Manufacture of measuring } \\
\text { instruments }\end{array}$ & 468 & $19,187,192$ & 08.01 .2020 \\
\hline C14 & Purchasing Manager & $\begin{array}{l}\text { Manufacture of electricity } \\
\text { control }\end{array}$ & 242 & $24,714,394$ & 23.01.2020 \\
\hline $\mathrm{C} 15$ & Production Manager & Metalworking & 45 & $1,906,378$ & 02.02 .2020 \\
\hline $\mathrm{C} 16$ & $\begin{array}{l}\text { Technological } \\
\text { Manager }\end{array}$ & $\begin{array}{l}\text { Manufacture of electronic } \\
\text { components }\end{array}$ & 2,300 & $223,906,496$ & 25.01 .2020 \\
\hline $\mathrm{C} 17$ & CEO & $\begin{array}{l}\text { Manufacture of other special- } \\
\text { purpose machinery }\end{array}$ & 55 & $5,537,102$ & 14.02 .2020 \\
\hline $\mathrm{C} 18$ & Technical Director & $\begin{array}{l}\text { Manufacture of other special- } \\
\text { purpose machinery }\end{array}$ & 183 & $16,598,375$ & 07.02 .2020 \\
\hline C19 & IT Manager & $\begin{array}{l}\text { Manufacture of electric } \\
\text { lighting equipment }\end{array}$ & 3,634 & $221,933,408$ & 18.02 .2020 \\
\hline $\mathrm{C} 20$ & HR Manager & $\begin{array}{l}\text { Manufacture of electronic } \\
\text { equipment for vehicles }\end{array}$ & 2,120 & $517,246,528$ & 13.01.2020 \\
\hline C21 & CEO & Manufacture of other furniture & 12 & 194,215 & 25.01.2020 \\
\hline $\mathrm{C} 22$ & CEO & $\begin{array}{l}\text { Manufacture of special } \\
\text { machinery }\end{array}$ & 174 & $19,198,792$ & 07.02 .2020 \\
\hline $\mathrm{C} 23$ & CEO & $\begin{array}{l}\text { Manufacture of other special- } \\
\text { purpose machinery }\end{array}$ & 36 & 4,291,704 & 18.02 .2020 \\
\hline
\end{tabular}

Table 1.

Summary of interviews

Notes: $\mathrm{CEO}=$ Chief executive officer; $\mathrm{HR}=$ human resource

The audio recording from this session was then transcribed for analysis purposes. For that final step, we used the assistance of ATLAS.ti (version 7). This tool is designed to help researchers to organise text, graphic, audio and visual data files, as well as subsequent coding. Once the data were organised, we then went back reading through each transcript, adding marginal notes and memos. In this coding phase, the data were broken down into manageable segments and given names or other identifiable labels. In essence, coding 
"requires constantly comparing and contrasting various successive segments of the data and subsequently categorizing them" (Schwandt, 2007, p. 32). This process could be repeated as many times as deemed necessary to get an exact sense of the whole data set. Overall, we included three main aspects of content analysis: description, analysis and interpretation of the leaders' opinion. We outline the data analysis more thoroughly in Section 4.

\section{Findings and discussions}

To provide an understanding of how Industry 4.0 technologies act as an important role in the corporate operation of the investigated companies, it is necessary first to examine the interpretation of Industry 4.0 from the leader's perception.

\subsection{Interpretation of Industry 4.0}

First, we clarify the interpretation of Industry 4.0 and provide our own definition based on the leader's perceptions. As a first step in the process, we retrieved all the related citations, the opinions on what Industry 4.0 meant to the surveyed companies (leader perception: Industry 4.0 code), then arranged the mentioned words in order of frequency (synonymous words were merged, e.g. automation, automated) and made a word cloud from it (using Atlas.ti and WordArt). The result is shown in Figure 2. The key elements are IT, labour, production, manufacturing, automation and processes.

According to the answers to Q1 (How do you interpret Industry 4.0?), several interviewees' interpretations are shown in Table 2.

By analysing the words that appear in the word cloud, and the leader's interpretations our definition is: "Industry 4.0, in addition to developing data and process flow automation, utilises the human factor in complex tasks in order to gain a better corporate position."
Influence of Industry 4.0 technologies

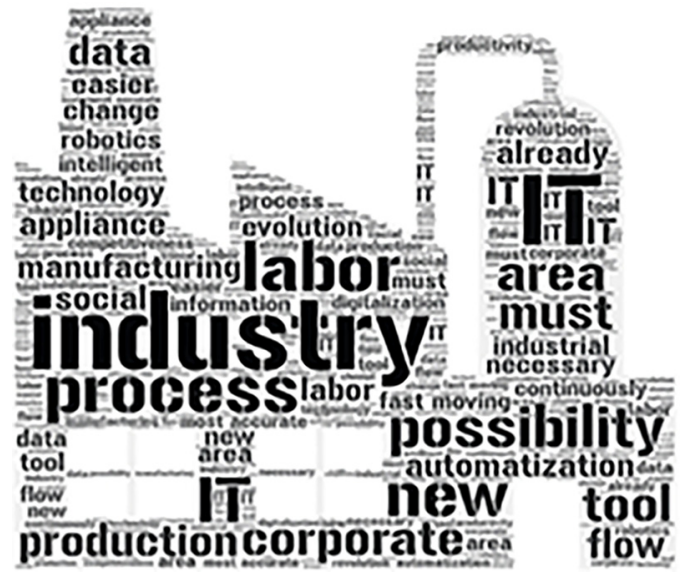

Figure 2. Industry 4.0 word cloud 


\begin{tabular}{|c|c|c|}
\hline & & \\
\hline $\begin{array}{l}\text { MIEDAR } \\
304\end{array}$ & Pseudonym & Industry 4.0 \\
\hline 1036 & $\mathrm{C} 4$ & $\begin{array}{l}\text { "Industry } 4.0 \text { is the relationship of production equipment, production planning and production } \\
\text { sub-processes with IT tools, which enables the transmission of demand in production with a very } \\
\text { short lead time, independent, automated equipment and robots in the production process, and the } \\
\text { parameters describing the production process can be monitored in real time" } \\
\text { "... we automate production and keep the human factor for more complex activities where we } \\
\text { are better than machines" }\end{array}$ \\
\hline & C5 & $\begin{array}{l}\text { "Robotisation, automation, and processes that make it possible to replace human labour with } \\
\text { machines" }\end{array}$ \\
\hline & $\mathrm{C} 10$ & "Labour carries out meticulous work, which cannot be replaced by a technology" \\
\hline & $\mathrm{C} 14$ & "... in the process of Industry 4.0, labour will never be $100 \%$ substitutable" \\
\hline Table 2. & C15 & $\begin{array}{l}\text { "possible replacement of automation, acceleration and simplification of tasks due to labour } \\
\text { shortages" }\end{array}$ \\
\hline $\begin{array}{l}\text { Leader's } \\
\text { interpretation of }\end{array}$ & $\mathrm{C} 19$ & $\begin{array}{l}\text { "Industry } 4.0 \text { is a potential opportunity to continue our automation efforts. One possible } \\
\text { solution to labour shortages could be" }\end{array}$ \\
\hline Indus & $\mathrm{C} 23$ & "It means an ever-closer intertwining of information technology and automation" \\
\hline
\end{tabular}

\subsection{Driving forces}

In the first stage of the analysis, we examined the driving forces of Industry 4.0 from a technological and human perspective (Q5. What are the driving forces that motivate you to implement Industry 4.0 technologies?'). We asked the leaders what motivates them to adopt new technologies and what factors have a positive effect on the company's performance. Based on the responses, it is clear that from a technological perspective, managers primarily want to increase corporate performance by using higher-level technologies. New trends in performance measurement have highlighted the fact that performance does not consist solely in measuring financial or quantitative indicators. Efficiency and productivity cannot always be measured by financial indicators:

$[\ldots$. ] increasing the efficiency of production motivates us. (C10)

[... .] I see an opportunity for development in the areas of planning and procurement, where an Io $\mathrm{T}$ solution can simplify and make our processes more efficient. We will be able to measure our corporate performance more specifically and accurately. (C11)

[... The implementation of Industry 4.0 technologies will help build a more efficient, transparent company. (C23)

Efficiency is a key indicator of corporate performance that is multi-faceted and can be interpreted in many ways. During the interviews, technological efficiency was mostly identified with speed, information flow and precision. The biggest advantage (most quotes) is seen in speed. This category includes time and costs savings, which can reduce the number of non-value-creating processes. Systems become more transparent so companies can respond more quickly to market changes:

[...] Reducing passive production time is a very important task for us. (C10)

[...] I have a positive experience, reducing our administrative work and fixing machine errors faster. (C13)

[...] based on the Lean approach, Industry 4.0 and IT offer opportunities to reduce losses (unnecessary waiting time, unnecessary operations). (C7) 
[...] The prototype is sent to the partner in file format (scanning) with computer models. They can modify it with their own software and make it visible with their own 3D printer. $[\ldots]$ the time to make the final product is shortened, any decor design can be made with a computer. (C8)

Interviewees highlighted the information flow in second place, which is partly related to the previous category. The role of information in business has increased in value. On the one hand, it has become important that data are available at the right time and in the right place at all times, and on the other hand, that new technology can provide accurate data about products and systems:

[. . .] Our machines are made with the focus that the data are available over the Internet. (C7)

[...] The new technology facilitates the production data query and adjustment of the machine parameters. (C13)

[...] We can get a more accurate picture of the operation of the machines by using sensor data, we can get information that can be useful for our customers. (C19)

[...] We build machines which extract information from the product and it is sent to the central database. [...] data processing signals the conformity of the product. (C3)

Respondents from small businesses mentioned manufacturing precision. Automation and a digital toolbar provide the ability to eliminate human error, which guarantees a higher level of quality and optimal use of materials:

[...] The use of new technologies is motivating because human errors and inaccuracies can be filtered out, there is less possibility of error. In addition, a higher degree of precision and quality can be achieved. (C2)

[...] We constantly monitor our processes, if we experience a discrepancy we intervene automatically. [...] precision is very important in metalworking. (C6)

[...] the loss (falling raw material) and the number of possible errors will be reduced, material utilisation will be more optimal, much more accurate. (C10)

From the perspective of interviewees, two trends seem to be outlined in relation to human resources and Industry 4.0. They can be motivated to replace human resources or support the workforce with new technologies. The two views are not completely opposed to each other. External factors and the operating structure of the company will determine which effect will be more pronounced. In case of the replacement of human resources, the driving force is primarily the appearance of labour shortages, which was mentioned by large enterprise executives:

[...] We are struggling with labour problems in the area so many Mongolian employees have appeared at the company (nearly 100 people). [...] Language problems are the most common here, although interpreters are used. The motivation in this case would be to replace the workforce. (C5)

[...] it would be a great help because we have a constant resource problem at our company, I think it would partially solve this problem. (C14) 
MEDAR 30,4
[...] Industry 4.0 is a potential opportunity to continue our automation efforts. It could be one possible solution to labour shortages. (C19)

Another motivation for the replacement of the human factor is the consideration of corporate performance, because as a result of automation, costs can be reduced and basic production processes can be accelerated:

[...] reduce personnel costs with machines. Substitution of living labour is present, there are machines that communicate with each other. (C8)

[... ] robotic service on the heat treatment side (switching from unskilled labour to robots). (C3)

[... ] Manual cutting is replaced by machine cutting. Cutting would be done with a machine which would significantly increase accuracy and economy. (C10)

[...] Automation has become necessary due to competitiveness. [.. .] The human factor has been crowded out of the process here. (C15)

Interviewees felt the supporting role of technology was stronger. This perspective emphasises the purpose of Industry 4.0 technologies to simplify the work of human resources and to create a more comfortable working environment. As a result of digitalisation, the workforce is being redeployed towards other types of value-creating processes. Furthermore, the human will not be replaceable in higher-level corporate processes:

[...] These motivate us to improve our processes, to mechanize production, and to reserve the human factor for more complex activities where we are better than machines. (C4)

[... The work of the auditor is facilitated by the ERP system because the system has all the data. $[\ldots .$.$] they don't have to do unnecessary things, they want a prepared, modern, creative world. (C7)$

[...] It is also positive that the workers do not have to know the production plans either, because everything can be managed online from the office. (C13)

[...] These systems make our work easier and also provide a much more attractive environment for our employees. (C18)

\subsection{Barriers of Industry 4.0}

In this section, we examined the inhibiting factors of technology and human resource with respect to the implementation of Industry 4.0 (Q6. What are the barriers that make it difficult) impossible to implement Industry 4.0 technologies?). In both cases, leaders mentioned many types of barriers. From a technological point of view, the biggest problem is compatibility. The relationship between technologies in business systems would be important in the selection and implementation of technology. It was mentioned mainly by large enterprise leaders that maintain a complement of machines with a wide range of technologies:

[...] The downside is that we have very "old" machines and we have new technology machines, but they are not compatible with each other at all. [... It is very difficult to find a way to connect different machines. (C16)

[... . The existing IT-supported systems are not sufficiently integrated, there is a lot of manual operation and data recording. (C4) 
Based on activity, compatibility difficulties were mentioned by special-purpose machine manufacturers. The diversity of market needs also requires the use of different technologies. The systems are different due to custom manufacturing, and it is difficult to find a common platform. In many cases, the market cannot offer a solution, as there are no suitable tools or technologies:

$[\ldots]$ There are too many different systems, they are not compatible, it is a disaster. (C7)

[... Compatibility is an ongoing issue and net coverage is inadequate (C17)

[...] The difficulties caused by the introduction of these applications is that we are unique machine manufacturers, and each device is different. It is difficult to buy software and technologies suitable for these tasks, it is not on the market. (C1)

A special case was explored in the area of labour selection. The labour selection robot is not compatible with the whole process; it can only be used for certain applications because it is uncomfortable and unusual for the applicant:

[...] Vera robot is not suitable for everything, it should be used only for pre-screening, because during the interview an "unpleasant" situation may develop. (C20)

According to leaders, the second key barrier to the introduction of Industry 4.0 technology is the adaptation process. Decision-making is not always the responsibility of the local company, because the permission of the foreign parent company is required for such largescale investments. This is accompanied by a significant preparation process that takes a lot of time during daily work:

[... . The decision will be made abroad, after it will be introduced in Hungary. It would be a great help because our company has a continuous resource problem, I think it would partially solve this problem, although it is not easy to accept and introduce such an investment [...] The related decisions are made by the parent company, which often slow down the process. (C14)

[... ] Developments hampered by dependence on XY Holding (authorisation procedure). (C17)

This effect is also reflected in the lives of small- and medium-sized enterprises. The focus in this case is on the customers and the internal administration process. These business leaders are likely to feel that they are more dependent on customers in the course of their operations. The burden of administrative work is felt more strongly due to the smaller number of employees and the uniqueness of the task:

[...] The main guidelines of the project to be implemented must be developed in consultation with our clients, and then the details will be prepared in accordance with local conditions and technology. (C1)

[...] What is slowing down is the amount of administrative work that is required. When making minimal machine modifications, the risk analysis needs to be re-done, documented in the manual, which don't seem like slow things, though they are. [...] Many people need to be consulted in the meantime, especially with external contractors and their workers. Lots of approvals, signature collection. (C6)

Respondent C22 sufficiently highlights the influencing effect of the human factor on the introduction of innovations:

[...] Of course, none of the novelties and innovations are easy to implement. The main influencing factor is human behaviour, human problems that make such developments difficult. (C22)
Influence of Industry 4.0 technologies 
MEDAR

30,4

1040
On the human side, the biggest challenge is caused by fear. According to managers, a significant portion of employees are afraid of new technology and change:

[...] There is a lot of fear in the workforce about the new, and the same is true for new technologies. (C20)

[...] many people are woody and do not want to be flexible which has a blocking effect. [...] the other type executes instructions with maximum indifference, industry 4.0 will drive them out, or eventually force learning. (C13)

Automation is often a danger in the eyes of the workforce, as they may think that machines will take their jobs. This view came mainly from small business leaders, where automation is not yet system wide:

[... . People are afraid of their work becoming unnecessary. (C15)

[...] Changes can also generate fear in the employee (e.g. There will be no need for an employee due to automation). (C10)

[...] They are afraid that they will have no job, they are not open, they fundamentally reject everything new. (C9)

Remarks about low enthusiasm and resistance have appeared in both large and small businesses, and in some cases, this has been expressed specifically in relation to older employees:

[...] Of course, nothing goes smoothly, there can be less resistance or doubt about any change. (C23)

[... . Older people are no longer so enthusiastic when they have to learn a new thing, they prefer to rely on their routine and stick to well-established methods. (C2)

[...] There are large generational differences, especially older workers who have more resistance. (C20)

Leaders have a big role to play in overcoming these fears. It is their duty and responsibility to provide adequate information and education about changes during the implementation phase. After a short time, resistance is replaced by acceptance:

[... .] There was resistance, grumbling, but people didn't quit, if they got used to the new system, they would come up with a new demand later. (C7)

Another group of concerns was related to data security. Industry 4.0 systems store and produce a wealth of data. Access to personal and corporate data appears to be a risk factor and creates mistrust of systems:

[...] Our tools collect a lot of information and data about us that we don't even know about and can abuse. (C2)

[...] In the initial phase, insecure devices provide opportunities for abuse, so I only support the deployment of truly tested Internet applications. (C13)

[... ] You secure yourself with a password and an ID and you think it works. It turns out everyone knows everything about you. These fears are in the person. (C22) 
One of the major critical points in implementing Industry 4.0 technologies at many surveyed companies is that there is a lack of skilled labour; the employees do not have the competencies required in the future;

[...]For us there is a need to develop digital skills. (C2)

[...] a different quality of workforce is needed now than later after the implementation of Industry 4.0. [...] At our company a critical point is the "competence", [...] with the new technology, the same workforce may not be as professional/efficient. (C10)

[...] lack of adequate workforces makes implementation difficult. (C9)

[...] The quality of the workforce has deteriorated, there is no adequate professional knowledge. (C21)

\subsection{Performance management dimensions}

Our results uncovered the following important driving forces such as efficiency with speed/ information flow/precision and barriers, such as technology compatibility, human fears and lack of digital skills in terms of Industry 4.0 implementation. Based on that result, we developed "DIGI-TEcH" performance management dimensions, which can be used to complete the corporate performance management system. We determined three dimensions and their elements, and besides, examples for key performance indicators and metrics are addressed in Table 3.

\section{Conclusion}

Overall, our study examined how surveyed companies interpret the concept of Industry 4.0, and the driving forces and barriers to implementing Industry 4.0 technologies.

The results do not show a difference in terms of differing company sizes. In discussion of the interpretation of Industry 4.0, our finding demonstrates a definition based on the opinion of Hungarian business leaders, which is similar to Lasi et al. (2014) and Davies (2015) from the technological point of view; however, the role of the human factor appears as an important new element; thus, our definition takes a more complex approach to the topic.

Based on the literature (Horváth and Szabó, 2019), the driving forces were tested from two sides: technology and human resource. Analyses have shown that efficiency is one of

\begin{tabular}{llll}
\hline Dimensions & Elements & KPIs & Metrics \\
\hline Technology & $\begin{array}{l}\text { Technology } \\
\text { compatibility }\end{array}$ & Continuous monitoring & Update availability \\
Efficiency & Speed & Lead time & $\begin{array}{l}\text { Patform compatibility } \\
\text { Unnecessary waiting time }\end{array}$ \\
& Information flow & $\begin{array}{l}\text { Availability of real-time } \\
\text { information }\end{array}$ & $\begin{array}{l}\text { Data provided by machines } \\
\text { Automatic data exchange }\end{array}$ \\
& Precision & Yield ratio & $\begin{array}{l}\text { Fraction defective } \\
\text { Number of failures }\end{array}$ \\
& Human fears & Attitude formation & Digital attitude development training \\
& Lack of digital skill & Level of digital skill & EUROpass digital skill grid
\end{tabular}

Note: ${ }^{a}$ European Commission (2017): DigComp 2.1: The Digital Competence Framework for Citizens
Influence of Industry 4.0 technologies 
MEDAR

30,4

1042

the most important factors, in line with the researchers' findings (Hofmann and Rüsch, 2017; Liao et al., 2017). Our research identified efficiency with speed, information flow and precision. Automated and faster processes reduce production time and costs, and these results are similar to those reported by Rojko (2017). According to Cimini et al. (2017), Industry 4.0 technologies help to manage faster decision-making which indirectly appeared in our qualitative analysis in the field of information flow. Respondents highlighted the continued availability of accurate data, which can support the necessary intervention. Industry 4.0 technology has changed attitudes towards the workforce. In line with Tabarés et al. (2018), advanced automation makes it possible to replace unskilled physical labour, so greater efficiency and corporate performance can be achieved. In addition, our research has shown that labour replacement is also influenced by labour shortages, according to largeenterprise leaders. In our results, the support of the workforce by advanced technologies has played a greater role. Similar to the results of Wang et al. (2016) and Nelles et al. (2016) automated systems can support the workforce because it simplifies workflows. According to the interviewees, human resources need to perform more complex activities in a digital environment. This confirms the finding of Tabarés et al. (2018) that digital competencies will be essential.

The literature review and our results show that Industry 4.0 involves challenges and barriers for companies. This paper identified three significant barrier factors to the implementation of Industry 4.0 technologies in manufacturing companies: technology compatibility, human fears and the lack of digital skills.

In line with Kiel et al. (2017b) and Nagy (2019), a major obstacle is the compatibility and standardisation problems. The diversity of market needs (mainly based on the customised manufacturing) requires the implementation of different technologies, and it is a serious challenge to find a common platform. Our findings show that a key barrier lies in the adoption process. Opposite to the results of Nagy et al. (2018), it is not a pressure of the foreign parent company but a permission which is required for implementing these technologies (as these are large-scale investments). It means a significant preparation process that takes a lot of time. However, we cannot derive a difference on the level of company size, but we can highlight that small and medium-sized enterprise leaders felt the administrative workload caused by the implementation of Industry 4.0 more strongly because of the smaller staff and the uniqueness of the tasks.

We identified that from the human perspective, the biggest challenge is caused by fear. According to interviewees, our findings are also consistent with previous studies, such as lack of understanding and fear of the new technology (Horváth and Szabó, 2019) and resistance of the workforce (Horváth and Szabó, 2019) - in our research, this was mainly a characteristic of older people. Similar to that reported by Kinzel (2017) and Horváth and Szabó (2019), employees are frightened of losing their job with increasing digital solutions and a major challenge for the surveyed companies ensuring data security (Kovács, 2017a, 2017b). Moreover, some of our interviewees mentioned the fear of change and changing environment as a general barrier. Our results indicated in parallel with those of Shamim et al. (2016), Müller et al. (2018), Kiel et al. (2017a) and Horváth and Szabó (2019) that one of the biggest barriers in implementing Industry 4.0 technologies is that companies do not have a skilled workforce (mainly mentioning advanced digital skills).

From a practical point of view, companies can extend their performance management system with the developed DIGI-TEcH dimensions. As the paper focusses on the employeerelated aspects of digital technologies, we provide some examples from a human point of view. Digital attitude development training of employees will be a key factor for the successful implementation of Industry 4.0 in the future, to instruct in the practical aspects of 
the increased complexity of digitised solutions. Regular communication with employees can also allay their doubts and fears. In addition, corporate management can use the impact of Industry 4.0 technology such as speed, information flow and precision for increasing efficiency and corporate performance. Company leaders should also help the employees to overcome their fears and anxiety, who may be frightened of the new technology and change and afraid of losing their jobs with increasing digitalisation and not having the appropriate skills to handle digitised technologies. It is their responsibility to provide adequate information and education to their employees replacing their resistance to acceptance. Besides, implementing compatible Industry 4.0 technologies may engender an acceptance within the company and decrease employee resistance.

As with most studies, this research offers interesting insights, but it is also affected by some limitations. As the paper focusses on Industry 4.0 implementation in Hungary, any comparison with other countries is limited. In line with Wang et al. (2016), who stated that this kind of research should be extended to non-Western countries, which have barely been examined, a comparison with different Central and Eastern European countries would be an interesting option for further research. Moreover, given the exploratory and qualitative nature, further quantitative research is needed to generalise the results. Finally, only manufacturing companies are examined. Thus, the results should not be directly applied to, for example, service companies. Therefore, future research would be useful to investigate the service sector in terms of Industry 4.0 implementation.

\section{References}

Aichholzer, G., Rhomberg, W., Gudowsky, N., Saurwein, F. and Weber, M. (2015), "Industry 4.0 background paper on the pilot project - Industry 4.0: foresight and technology assessment on the social dimension of the next industrial revolution", Austrian Academy of Sciences, Vienna, Austria, doi: 10.1553/ITA-PB-A69-3.

Appio, F.P., Frattini, F., Petruzzelli, A.M. and Neirotti, P. (2021), "Digital transformation and innovation management: a synthesis of existing research and an agenda for future studies", Journal of Product Innovation Management, Vol. 38 No. 1, pp. 4-20, doi: 10.1111/jpim.12562.

Ardito, L., D’Adda, D. and Petruzzeli, A.M. (2018), "Mapping innovation dynamics in the Internet of Things domain: evidence from patent analysis", Technological Forecasting and Social Change, Vol. 136, pp. 317-330, doi: 10.1016/j.techfore.2017.04.022.

Ardito, L., Petruzzelli, A.M., Panniello, U. and Garavelli, A.C. (2019a), "Towards Industry 4.0: mapping digital technologies for supply chain management-marketing integration", Business Process Management Journal, Vol. 25 No. 2, pp. 323-346, doi: 10.1108/BPMJ-04-2017-0088.

Ardito, L., Scuotto, V., Del Giudice, M. and Petruzzelli, A.M. (2019b), “A bibliometric analysis of research on big data analytics for business and management", Management Decision, Vol. 57 No. 8, pp. 1993-2009, doi: 10.1108/MD-07-2018-0754.

Bai, C., Dallasega, P., Orzes, G. and Sarkis, J. (2020), "Industry 4.0 technologies assessment: a sustainability perspective", International Journal of Production Economics, Vol. 229, p. 107776, doi: 10.1016/j.ijpe.2020.107776.

Berg, M. and Hudson, P. (1992), "Rehabilitating the industrial revolution", The Economic History Review, Vol. 45 No. 1, pp. 24-50, doi: 10.2307/2598327.

Blanchet, M. and Rinn, T. (2016), "The Industrie 4.0 transition quantified”, Roland Berger Think Act, Munich, available at: www.rolandberger.com/publications/publication_pdf/roland_berger_industry_40_ 20160609.pdf (accessed 20 March 2020).

Blanchet, M., Rinn, T., Thaden, V.G. and Thieulloy, G. (2014), "Industry 4.0 - the new industrial revolution, how Europe will succeed", Roland Berger Think Act, Munich, available at: www. iberglobal.com/files/Roland_Berger_Industry.pdf (accessed 16 December 2020).
Influence of Industry 4.0 technologies

1043 
MEDAR 30,4

Brettel, M., Friederichsen, N., Keller, M. and Rosenberg, M. (2014), "How virtualization, decentralization and network building change the manufacturing landscape: an Industry 4.0 perspective", International Journal of Science Engineering and Technology, Vol. 8 No. 1, pp. 37-44, doi: 10.5281/ zenodo.1336426.

Castelo-Branco, I., Cruz-Jesus, F. and Oliveira, T. (2019), "Assessing Industry 4.0 readiness in manufacturing: evidence for the European Union”, Computers in Industry, Vol. 107, pp. 22-32, doi: 10.1016/j.compind.2019.01.007.

Ceipek, R., Hautz, J., Petruzzelli, A.M., De Massis, A. and Matzelr, K. (2020), “A motivation and ability perspective on engagement in emerging digital technologies: the case of Internet of Things solutions", Long Range Planning, Vol. 54 No. 5, doi: 10.1016/j.lrp.2020.101991.

Cimini, C., Pinto, R., Pezzotta, G. and Gaiardelli, P. (2017), "The transition towards industry 4.0: business opportunities and expected impacts for suppliers and manufacturers", Proceedings of IFIP International Conference on Advances in Production Management Systems, Cham, Springer, pp. 119-126, doi: 10.1007/978-3-319-66923-6_14.

Constantiou, I.D. and Kallinikos, J. (2015), "New games, new rules: big data and the changing context of strategy", Journal of Information Technology, Vol. 30 No. 1, pp. 44-57, doi: 10.1057/jit.2014.17.

Correani, A., De Massis, A., Frattini, F., Petruzzelli, A.M. and Natalicchio, A. (2020), "Implementing a digital strategy: learning from the experience of three digital transformation projects", California Management Review, Vol. 62 No. 4, pp. 37-56, doi: 10.1177/0008125620934864.

D'Ippolito, B., Petruzzelli, A.M. and Panniello, U. (2019), "Archetypes of incumbents' strategic responses to digital innovation", Journal of Intellectual Capital, Vol. 20 No. 5, pp. 662-679, doi: 10.1108/JIC-04-2019-0065.

Dalenogare, L.S., Benitez, G.B., Ayala, N.F. and Frank, A.G. (2018), "The expected contribution of Industry 4.0 technologies for industrial performance", International Journal of Production Economics, Vol. 204, pp. 383-394, doi: 10.1016/j.ijpe.2018.08.019.

Dassisti, M., Giovannini, A., Merla, P., Chimienti, M. and Panetto, H. (2019), "An approach to support Industry 4.0 adoption in SMEs using a core-metamodel", Annual Reviews in Control, Vol. 47, pp. 266-274, doi: 10.1016/j.arcontrol.2018.11.001.

Davies, R. (2015), "Industry 4.0 digitalisation for productivity and growth", available at: www.europarl.europa. eu/RegData/etudes/BRIE/2015/568337/EPRS_BRI(2015)568337_EN.pdf (accessed 19 March 2020).

Del Vecchio, P., Di Minin, A., Petruzzelli, A.M., Panniello, U. and Pirri, S. (2018), "Big data for open innovation in SMEs and big corporations: trends, opportunities, and challenges", Creativity and Innovation Management, Vol. 27 No. 1, pp. 6-22, doi: 10.1111/caim.12224.

Demeter, K., Losonci, D., Nagy, J. and Horváth, B. (2019), “Tapasztalatok az ipar 4.0-val - egy esetalapú elemzés", Vezetéstudomány/Budapest Management Review, Vol. 50 No. 4, pp. 11-23, doi: 10.14267/VEZTUD.2019.04.02.

Dorst, K. (2015), Frame Innovation, Cambridge, MA, MIT Press, doi: 10.7551/mitpress/10096.001.0001.

European Commission (2017), "European countries join forces to digitise industry", available at: https:/ec. europa.eu/digital-single-market/en/news/european-countries-join-forces-digitise-industry (accessed 19 March 2020).

European Commission (2020), "Digital economy and society index (DESI) 2020 human capital", available at: www.ikanos.eus/wp-content/uploads/2020/06/DESI2020Thematicchapters-Humancapital.pdf (accessed 17 December 2020).

Geissbauer, R., Schrauf, S. and Hentrich, C. (2016), "The Industry 4.0/digital operations selfassessment”, PricewaterhouseCoopers Report, available at: https://i40-self-assessment.pwc.de/ i40/landing/ (accessed 14 September 2019).

George, R.A., Siti-Nabiha, A.K., Jalaludin, D. and Abdalla, Y.A. (2016), "Barriers to and enablers of sustainability integration in the performance management systems of an oil and gas company", Journal of Cleaner Production, Vol. 136, pp. 197-212, doi: 10.1016/j.jclepro.2016.01.097. 
Ghobakhloo, M. (2018), “The future of manufacturing industry: a strategic roadmap toward Industry 4.0", Journal of Manufacturing Technology Management, Vol. 29 No. 6, pp. 910-936, doi: 10.1108/ JMTM-02-2018-0057.

Gibson, I., Rosen, D., Stucker, B. and Khorasani, M. (2014), Additive Manufacturing Technologies, New York, NY, Springer, doi: 10.1007/978-1-4419-1120-9.

Gracel, J. and Lebkowski, P. (2018), "The concept of industry 4.0 related manufacturing technology maturity model (Manutech Maturity Model, MTMM)", Decision Making in Manufacturing and Services, Vol. 12 Nos 1/2, pp. 17-31, doi: 10.7494/dmms.2018.12.1-2.17.

Greenwood, J. and Jovanovic, B. (1999), "The information-technology revolution and the stock market", American Economic Review, Vol. 89 No. 2, pp. 116-122, doi: 10.1257/aer.91.5.1203.

Hecklau, F., Galeitzke, M., Flachs, S. and Kohl, H. (2016), "Holistic approach for human resource management in Industry 4.0", Procedia CIRP, Vol. 54, pp. 1-6, doi: 10.1016/j.procir.2016.05.102.

Hofmann, E. and Rüsch, M. (2017), "Industry 4.0 and the current status as well as future prospects on logistics”, Computers in Industry, Vol. 89, pp. 23-34, doi: 10.1016/j.compind.2017.04.002.

Horváth, D. and Szabó, R.Z. (2019), "Driving forces and barriers of Industry 4.0: do multinational and small and medium-sized companies have equal opportunities?", Technological Forecasting and Social Change, Vol. 146, pp. 119-132, doi: 10.1016/j.techfore.2019.05.021.

Jääskeläinen, A. and Sillanpää, V. (2013), "Overcoming challenges in the implementation of performance measurement: case studies in public welfare services", International Journal of Public Sector Management, Vol. 26 No. 6, pp. 440-454, doi: 10.1108/IJPSM-12-2011-0014.

Jankowska, B. and Götz, M. (2017), “Clusters and industry 4.0 - do they fit together?”, European Planning Studies, Vol. 25 No. 9, pp. 1633-1653, doi: 10.1080/09654313.2017.1327037.

Jeschke, S., Brecher, C., Meisen, T., Özdemir, D. and Eschert, T. (2017), "Industrial internet of things and cyber manufacturing systems", Industrial Internet of Things, Cham, Springer, pp. 3-19, doi: 10.1007/978-3-319-42559-7_1.

Kaasinen, E., Schmalfuß, F., Özturk, C., Aromaa, S., Boubekeur, M., Heilala, J., Heikkiläa, P., Kuulaa, T., Liinasuoa, M., Machb, S., Mehtac, R., Petäjäd, E. and Waltere, T. (2020), "Empowering and engaging industrial workers with Operator 4.0 solutions", Computers and Industrial Engineering, Vol. 139, pp. 1-13, doi: 10.1016/j.cie.2019.01.052.

Kagermann, H., Wahlster, W. and Helbig, J. (2013), "Recommendations for implementing the strategic initiative INDUSTRIE 4.0", Final report of the Industrie 4.0 Working Group, Acatech, Frankfurt am Main, Germany.

Kaivo-Oja, J., Roth, S. and Westerlund, L. (2017), "Futures of robotics: human work in digital transformation”, International Journal of Technology Management, Vol. 73 No. 4, pp. 176-205, doi: 10.1504/IJTM.2017.10004003.

Kiel, D., Arnold, C. and Voigt, K.I. (2017a), "The influence of the industrial internet of things on business models of established manufacturing companies - a business level perspective", Technovation, Vol. 68, pp. 4-19, doi: 10.1016/j.technovation.2017.09.003.

Kiel, D., Müller, J.M., Arnold, C. and Voigt, K.I. (2017b), "Sustainable industrial value creation: benefits and challenges of industry 4.0", International Journal of Innovation Management, Vol. 21 No. 8, p. 1740015, doi: 10.1142/S1363919617400151.

Kinzel, H. (2017), "Industry 4.0 - where does this leave the human factor?", Journal of Urban Culture Research, Vol. 15 No. December, pp. 70-83, doi: 10.14456/jucr.2017.14.

Koleva, N. (2019), "An empirical study on human resources' attitude towards manufacturing digitalization", Proceedings of International Conference on Creative Business for Smart and Sustainable Growth (CREBUS), Sandanski, Bulgaria, pp. 1-5, doi: 10.1109/CREBUS.2019.8840057.

Kovács, O. (2017a), “Az ipar 4.0 komplexitása - I”, Közgazdasági Szemle, Vol. 64 Nos 7/8, pp. 823-851, doi: 10.18414/KSZ.2017.7-8.823. 
MEDAR 30,4

Kovács, O. (2017b), “Az ipar 4.0 komplexitása - II”, Közgazdasági Szemle, Vol. 64 No. 9, pp. 970-987, doi: 10.18414/KSZ.2017.9.970.

KSH (2019), "Helyzetkép az iparról, 2019”, available at: www.ksh.hu/docs/hun/xftp/idoszaki/jelipar/ 2019/index.html (accessed 18 January 2020).

Lasi, H., Fettke, P., Kemper, H.G., Feld, T. and Hoffmann, M. (2014), "Industry 4.0", Business and Information Systems Engineering, Vol. 6 No. 4, pp. 239-242, doi: 10.1007/s12599-014-0334-4.

Liao, Y., Deschamps, F., Loures, E., de, F.R. and Ramos, L.F.P. (2017), "Past, present and future of Industry 4.0 - a systematic literature review and research agenda proposal", International Journal of Production Research, Vol. 55 No. 12, pp. 3609-3629, doi: 10.1080/00207543.2017.1308576.

Lichtblau, K., Stich, V., Bertenrath, R., Blum, M., Bleider, M. and Millack, A. (2015), IMPULS-Industrie 4.0-Readiness, Impuls-Stiftung des VDMA, Aachen-Köln.

Losonci, D., Takács, O. and Városiné Demeter, K. (2019), "Az ipar 4.0 hatásainak nyomában - a magyarországi jármúipar elemzése”, Közgazdasági Szemle, Vol. 66 No. 2, pp. 185-218, doi: 10.18414/KSZ.2019.2.185.

Madolla, C., Petruzzelli, A.M., Percoco, G. and Urbinati, A. (2019), "Building a digital twin for additive manufacturing through the exploitation of blockchain: a case analysis into the aircraft industry", Computers in Industry, Vol. 109, pp. 134-152, doi: 10.1016/j.compind.2019.04.011.

Magistretti, S., Dell'Era, C. and Petruzzelli, A.M. (2019), "How intelligent is Watson? Enabling digital transformation through artificial intelligence", Business Horizons, Vol. 62 No. 6, pp. 819-829, doi: 10.1016/j.bushor.2019.08.004.

Melnyk, S.A., Bititci, U., Platts, K., Tobias, J. and Andersen, B. (2014), "Is performance measurement and management fit for the future?", Management Accounting Research, Vol. 25 No. 2, pp. 173-186, doi: 10.1016/j.mar.2013.07.007.

Ministry for National Economy (2016), "Irinyi industrial policy plan" (Irinyi terv, in Hungarian), available at: www.kormany.hu/download/d/c1/b0000/Irinyiterv.pdf (accessed 14 November 2019).

Mokyr, J. (1998), “The political economy of technological change: resistance and innovation in economic history", in Berg, M. and Bruland, K. (Eds), Technological Revolutions in Europe Edward Elgar Publishers, pp. 39-64.

Morrar, R., Arman, H. and Mousa, S. (2017), "The fourth industrial revolution (Industry 4.0): a social innovation perspective", Technology Innovation Management Review, Vol. 7 No. 11, pp. 12-20, doi: 10.22215/TIMREVIEW/1117.

Müller, J.M., Kiel, D. and Voigt, K. (2018), "What drives the implementation of Industry 4.0? The role of opportunities and challenges in the context of sustainability", Sustainability, Vol. 10 No. 1, p. 247, doi: $10.3390 /$ su10010247.

Nagy, J. (2019), “Az ipar 4.0 fogalma és kritikus kérdései - vállalati interjúk alapján”, Vezetéstudomány/ Budapest Management Review, Vol. 50 No. 1, pp. 14-26, doi: 10.14267/VEZTUD.2019.01.02.

Nagy, C., Molnár, E. and Kiss, É. (2020), "Industry 4.0 in a dualistic manufacturing sector-qualitative experiences from enterprises and their environment, Eastern Hungary", Hungarian Geographical Bulletin, Vol. 69 No. 2, pp. 157-174, doi: 10.15201/hungeobull.69.2.5.

Nagy, J., Oláh, J., Erdei, E., Máté, D. and Popp, J. (2018), "The role and impact of Industry 4.0 and the internet of things on the business strategy of the value chain - the case of Hungary", Sustainability, Vol. 10 No. 10, p. 3491, doi: 10.3390/su10103491.

Neely, A. (2005), "The evolution of performance measurement research: developments in the last decade and a research agenda for the next", International Journal of Operations and Production Management, Vol. 25 No. 12, pp. 1264-1277, doi: 10.1108/01443570510633648.

Nelles, J., Kuz, S., Mertens, A. and Schlick, C.M. (2016), "Human-centered design of assistance systems for production planning and control: the role of the human in industry 4.0", Industrial 
Technology (ICIT), IEEE International Conference 2016, pp. 2099-2104, doi: 10.1109/ ICIT.2016.7475093.

Oztemel, E. and Gursev, S. (2020), "Literature review of Industry 4.0 and related technologies", Journal of Intelligent Manufacturing, Vol. 31 No. 1, pp. 127-182, doi: 10.1007/s10845-018-1433-8.

Pazin, Ž. (2017), "Factories 4.0: the future of European manufacturing", available at: https://ec.europa.eu/ digital-single-market/en/blog/factories-40-future-european-manufacturing (accessed 29 November 2017).

Peters, M.D., Wieder, B., Sutton, S.G. and Wakefield, J. (2016), "Business intelligence systems use in performance measurement capabilities: implications for enhanced competitive advantage", International Journal of Accounting Information Systems, Vol. 21, pp. 1-17, doi: 10.1016/j. accinf.2016.03.001.

Pongrácz, F. and Nick, G. (2017), "Innováció- a fenntartható növekedés kulcsa magyarországon", Közgazdasági Szemle, LXIV.évf. július - Augusztus, Vol. 64 Nos 7/8, pp. 723-737, doi: 10.18414/ KSZ.2017.7-8.723.

Qin, J., Liu, Y. and Grosvenor, R. (2016), “A categorical framework of manufacturing for Industry 4.0 and beyond”, Procedia Cirp, Vol. 52, pp. 173-178, doi: 10.1016/j.procir.2016.08.005.

Robert, M., Giuliani, P. and Gurau, C. (2020), "Implementing Industry 4.0 real-time performance management systems: the case of Schneider Electric", Production Planning and Control, pp. 1-17, doi: $10.1080 / 09537287.2020 .1810761$.

Rojko, A. (2017), "Industry 4.0 concept: background and overview", International Journal of Interactive Mobile Technologies (IJIM), Vol. 11 No. 5, pp. 77-90, doi: 10.3991/ijim.v11i5.7072.

Saggiomo, M., Loehrer, M., Kerpen, D., Lemm, J. and Gloy, Y. (2016), "Human- and task-centered assistance systems in production processes of the textile industry: determination of operatorcritical weaving machine components for AR-prototype development", Proceedings of 49th Hawaï International Conference on System Sciences (HICSS), pp. 560-568, doi: 10.1109/ HICSS.2016.76.

Sahlin, J. and Angelis, J. (2019), "Performance management systems: reviewing the rise of dynamics and digitalization", Cogent Business and Management, Vol. 6 No. 1, p. 1642293, doi: 10.1080/ 23311975.2019.1642293.

Schumacher, A., Erol, S. and Sihn, W. (2016), "A maturity model for assessing Industry 4.0 readiness and maturity of manufacturing enterprises”, Procedia Cirp, Vol. 52, pp. 161-166, doi: 10.1016/j. procir.2016.07.040.

Schwandt, T.A. (2007), The Sage Dictionary of Qualitative Inquiry, Thousand Oaks, CA, Sage, 10.4135/ 9781412986281.

Secundo, G., Del Vecchio, P., Dumay, J. and Passiante, G. (2017), "Intellectual capital in the age of big data: establishing a research agenda", Journal of Intellectual Capital, Vol. 18 No. 2, pp. 242-261, doi: 10.1108/JIC-10-2016-0097.

Shamim, S., Cang, S., Yu, H. and Li, Y. (2016), "Management approaches for Industry 4.0: a human resource management perspective", IEEE Congress on Evolutionary Computation (CEC), pp. 5309-5316, doi: 10.1109/CEC.2016.7748365.

Ś lusarczyk, B. (2018), "Industry 4.0 - are we ready?", Polish Journal of Management Studies, Vol. 17 No. 1, pp. 232-248, doi: 10.17512/pjms.2018.17.1.19.

Szalavetz, A. (2019), "Industry 4.0 and capability development in manufacturing subsidiaries", Technological Forecasting and Social Change, Vol. 145, pp. 384-395, doi: 10.1016/j. techfore.2018.06.027.

Tabarés, R., Bartolomé, T., Martelloni, L., Marmo, D., de Amicis, L., Binenti, S., Rushton, E., Billy, L., Sebastianelli, A.F.M., García, J. and Shapiro, A. (2018), "Towards the popularization of open manufacturing in European industry", White Paper Version 2.0, Openmaker Riport, doi: 10.13140/RG.2.2.20410.64964. 
MEDAR

30,4

1048
Trstenjak, M. and Cosic, P. (2017), "Process planning in Industry 4.0 environment”, Procedia Manufacturing, Vol. 11, pp. 1744-1750, doi: 10.1016/j.promfg.2017.07.303.

Uden, L. and He, W. (2017), "How the Internet of Things can help knowledge management: a case study from the automotive domain", Journal of Knowledge Management, Vol. 21 No. 1, pp. 57-70, doi: 10.1108/JKM-07-2015-0291.

Veeraraghavan, S. and Punjabi, A. (2018), "How SAP's intelligent enterprise can help technology, media, and telecom (TMT) companies in their 'connected supply chain' journey towards Industry 4.0 evolution", PriceWaterhouseCoopers Report, available at: https://www.pwc.com/us/ en/services/alliances/assets/pwc-sap-intelligent-enterprise-and-industry-4-0.pdf (accessed 14 September 2019).

Veza, I., Mladineo, M. and Gjeldum, N. (2015), "Managing innovative production network of smart factories", IFAC-PapersOnLine (INCOM 2015), Vol. 48 No. 3, pp. 555-560, doi: 10.1016/j. ifacol.2015.06.139.

Wang, L., Törngren, M. and Onori, M. (2015), "Current status and advancement of cyber-physical systems in manufacturing”, Journal of Manufacturing Systems, Vol. 37 No. 2, pp. 517-527, doi: 10.1016/j.jmsy.2015.04.008.

Wang, S., Wan, J., Li, D. and Zhang, C. (2016), "Implementing smart factory of Industrie 4.0: an outlook", International Journal Distributed Sensors Networks, Vol. 12 No. 1, pp. 1-10, doi: 10.1155/2016/ 3159805.

Wang, Y., Ma, H.S., Yang, J.H. and Wang, K.S. (2017), "Industry 4.0: a way from mass customization to mass personalization production", Advances in Manufacturing, Vol. 5 No. 4, pp. 311-320, doi: 10.1007/s40436-017-0204-7.

Wittenberg, C. (2016), "Human-CPS interaction - requirements and human-machine interaction methods for the Industry 4.0", IFAC-PapersOnLine, Vol. 49 No. 19, pp. 420-425, doi: 10.1016/j. ifacol.2016.10.602.

Xu, L.D., Xu, E.L. and Li, L. (2018), "Industry 4.0: state of the art and future trends", International Journal of Production Research, Vol. 56 No. 8, pp. 2941-2962, doi: 10.1080/00207543.2018.1444806.

Yin, R.K. (2014), Case Study Research: Design and Methods, Los Angeles, Sage, doi: 10.3138/ cjpe.30.1.108.

Zhong, R.Y., Xu, X., Klotz, E. and Newman, S.T. (2017), "Intelligent manufacturing in the context of industry 4.0: a review”, Engineering, Vol. 3 No. 5, pp. 616-630, doi: 10.1016/J.ENG.2017.05.015.

\section{Corresponding author}

Nóra Obermayer can be contacted at: obermayer.nora@gtk.uni-pannon.hu 
Appendix

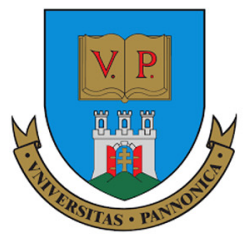

Thematic Excellence Program 2019 the grant of the Hungarian Ministry for Innovation and Technology (Grant Number: NKFIH-843-10/2019)
Influence of Industry 4.0 technologies

\section{Interview protocol}

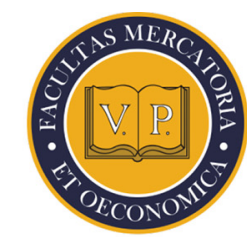

\section{IMPLEMENTATION AND INTERPRETATION OF INDUSTRY 4.0}

1. How do you interpret Industry 4.0 ?

2. In what areas does Industry 4.0 appear and what solutions does your company use?

3. What experiences do you have with this?

\section{LEADERS' PERSPECTIVES ON BARRIERS AND DRIVERS FOR INDUSTRY 4.0 IMPLEMENTATION}

4. In which areas do you consider the possibility and / or need to apply new technologies in your company to be particularly important?

5. What are the driving forces that motivate you to implement Industry 4.0 technologies?

6. What are the barriers that make it difficult / impossible to implement Industry 4.0 technologies?

7. What changes do you experience in the quality / composition / readiness / "mindset" / expectations, etc. of the workforce?

8. How comfortable do you feel in the online environment?

9. What types of online tools do you personally use?

10. Which would you prefer? What are you afraid of?

\section{NEED FOR TRAINING}

11. Do you consider that it is important to prepare managers and employees to deal with the expected changes / challenges, have you done that so far, or do you plan it?

12. Does the company's training plan include digital knowledge competence development training for both employees and managers? Do they seek possibility from outside of the company?

13. If you have to develop a training program, what kind of competences do you focus on? What training would you be willing to sacrifice money and time for yourself and your staff? 